\title{
Rāmāyaṇa Traditions in Bali
}

\author{
Helen Creese
}

The unique status of the KR as the only surviving Kakawin dating from the Central Javanese period has ensured its place in Indonesia's cultural and literary history. A key item in the Sanskrit 'repertory of cultural forms in the package of empire' (Pollock 1996:199, 2006), the central place of the Rāmāyana tradition is evidenced in the richness of its multi-faceted representations. From its earliest renderings on palm leaf and stone, it served as a source of political, strategic and moral guidance for rulers and as the inspiration for generations of poets, artisans and performers.

On Bali, where the Rāmāyaṇa's significant stylistic and thematic influence has endured until the present, the Old Javanese Rāmāyana is regarded as the Adi-Kakawin (Hooykaas 1957, 1958c; Robson 1972), that is, as both the first Kakawin and as the preeminent example of the Kakawin genre. ${ }^{1}$ For over a millennium, the Old Javanese KR has remained a powerful force in the cultural, literary and religious life of the Balinese. Nevertheless, just as elsewhere in South and Southeast Asia, on Bali too, there is no single 'Rāmāyaṇa' but instead a number of distinct literary, visual and performing arts representations that have each contributed to the creativity that underpins the vitality of Rāmayana traditions broadly considered.

This chapter will provide a regional perspective on Kakawins from Bali that are linked to this enduring Rāmāyana tradition. This survey will take us far from the origins of the KR in ninth-century Java, and even further from any consideration of the specific linguistic and stylistic influences of Sanskrit on Old Javanese. Instead, it will explore Kakawin representations of the Rāmāyana story at the far end of the chain of transmission. Most of these Kakawin were composed from the late eighteenth century onwards although the earliest

1. Since Indian tradition hails the Vālmìki Rāmāyaṇa as the Ādikāvya (Brockington 1998:1; Saran and Khanna 2004:1), this designation may well be less an indigenous category than a concept borrowed from Sanskrit literature, but it is, nonetheless, a designation that has been perpetuated by both Old Javanese Rāmāyaṇa scholarship and local Balinese tradition alike. 
examples may date from the sixteenth century. Because of the crucial role that Balinese manuscript traditions have played in the development and preservation of Old Javanese literature more generally, it will also touch on the continuities that can be traced in the adaptation and evolution of textual knowledge shared between Java and Bali over the longer term.

\section{A new Rāmāyaṇa}

In 2003, the literary achievements of I Wayan Pamit (b. 1935), a respected and well-known author and a strong proponent and supporter of Balinese culture, language and traditional literature, were recognized with the conferral of the provincial-level 'Dharma Kusuma' award. One year earlier, I Wayan Pamit had published four of his original Kakawin compositions: the two-volume Kakawin Ràwaña, the Nìla Candra, the Candra Bhuwana and the Candra Bhairawa (Pamit 2002a, 2002b, 2002c, 2002d). In 2006, he was again recognized, this time as one of Bali's six most prominent literary figures, in the inaugural round of the provincial 'Widya Pataka' awards. Now in his 7os, I Wayan Pamit, a former school teacher, has been involved in classical Balinese literature as an observer, composer and performer since he was seven years old. The Kakawin Rāwaṇa details Rāwaṇa's entire life from his birth to his death. It is a voluminous work of 117 cantos, composed in Old Javanese; with its accompanying Balinese gloss (ť̌gěs) printed on each facing page, it stretches to over 400 pages. He had completed this work several years earlier but had been unable to find a publisher until 2002. Wayan Pamit's focus on the character of the archetypal villain, Rāwaṇa, rather than on the quintessential hero, Rāma, attracted interest and some local criticism. In an interview with Darma Putra for the Bali Post on 7 September $2003,{ }^{2}$ Wayan Pamit claimed that Rāwana's character provided more than ample scope for the didactic exposition of the core moral and social values he wished to highlight for contemporary Balinese. He noted that his composition was based on his reading of a wide variety of lontar and other sources, including the Bhagavadgìtā and Nitiśästra and, it would seem, in particular the Uttarakanda (UtK), as we will explore in more detail below.

In his interest in the didactic possibilities of the Rammanyana story, Wayan Pamit proves himself a worthy twenty-first century heir to one of the longstanding, characteristic aims of Kakawin composition, that is, to provide edifying, morally-uplifting teachings on right conduct (dharma) to individuals and 'a sort of pattern for princes' (Friederich 1959:17) for those who govern.

2. http://www.balipost.co.id/BaliPostcetak/2003/9/7/pot2.html (accessed 13-4-2009). 
These lessons remain central to Balinese identity formation even in contemporary times, and have found a ready audience under the renewed impetus of the Ajeg Bali movement which seeks to foster a resilient and strong Balinese culture based on deeply-held religious and cultural traditions (Allen and Palermo 2005; Schulte Nordholt 2005). Indeed, 'traditional' literary life is flourishing in Bali in unprecedented ways, particularly in the electronic media on radio and television (Putra 2009; Creese 2009a).

Moreover, in his use of textual sources, in drawing on the UtK, the tenthcentury Old Javanese prose rendition of the final kānda of Vālmiki's epic composed during the reign of Dharmawangśa (r. 990-1016), I Wayan Pamit typifies the centuries-long Balinese compositional and thematic reliance on the Old Javanese prose versions of the Sanskrit epics. For, rather than the Old Javanese Kakawin version of the Ramayana, it is the UtK that sits at the centre of the development of Rammanyana textual traditions in Bali. While the UtK is not strictly speaking one of the Parwas since it is not a prose rendering of one of the 18 Parwas of the Mahäbhärata, as Zoetmulder (1974:83) notes, it is in every respect similar 'in treatment of the subject matter, in language and in style'. We know that the Old Javanese Parwa provided one of the primary sources for Mahābhârata-inspired Kakawin composition in Bali (Creese 1998:65-84, 1999:56-8). Similarly, in the development of Ramanyana traditions, the UtK has remained a key source of literary inspiration. For, in addition to the traditional core themes of Rāwaṇa's abduction of Sītā and Rāma's subsequent defeat of his enemy, Balinese poets have produced creative works based around 'satellite' stories and figures from the Rammanyana cycle. Many of these later Balinese compositions were ignored or dismissed by earlier generations of scholars, for example, Zoetmulder (1974) and Pigeaud (1967, 1968, 1970, 1980), as being of little value or no literary merit. In the last several decades, however, our perceptions of 'texts' and of the literary canon have changed dramatically. We have long-since moved away from the earlier stereotype of the Balinese merely as 'preservers' of the Old Javanese literary and textual heritage. Rather than being viewed as a moribund tradition dedicated to preserving earlier Javanese 'classics', it is now recognized that the Balinese contribution to Old Javanese literature was equally a creative one. This chapter, then, seeks to document some examples of this Kakawin literary creativity in Bali directly inspired by Old Javanese Rāmāyana traditions.

\section{The Balinese Kakawin tradition}

The consideration here of the Balinese Kakawin works that are linked to Old Javanese Ràmāyaña traditions necessarily elides a number of important ques- 
tions concerning Balinese textual and literary history. There is overwhelming evidence for the existence of a long and deep Sanskrit-influenced textual tradition in the Indonesian archipelago. This tradition encompassed many forms of textual knowledge, not just epic traditions and courtly literature but also religion, philosophy, language, law and so on. The exact nature of this shared cultural and textual world remains obscure and we know relatively little about the local and regional networks in which Kakawins thrived. Nevertheless the sheer scope of the Balinese textual heritage points to complex and multilayered interactions of long standing between Java and Bali, as linked components of an Old Javanese ecumene that arose in response to the expansive Sanskrit cosmopolis in premodern South and Southeast Asia (Pollock 2006). Until the end of the Majapahit period at least, some level of ongoing direct contact was maintained between Java and the Indian subcontinent. Even as late as the end of the fifteenth century when the last dated East Javanese Kakawin, the Siwarätrikalpa, was composed, there is clear evidence of links with South India (Teeuw et al. 1969). But what of Bali?

We do not know whether Sanskrit literary, cultural and religious traditions were mediated entirely through Java, or whether Balinese writers and scholars maintained an independent literary tradition that brought them into direct contact with India over a period of many centuries. What we can be certain of, however, is the fact that Kakawins were being composed in Bali in the Old Javanese language in a period long after Kakawin-writing had ceased to be a mode of creative expression on Java itself. More than a hundred such Balinese Kakawins are recorded (Creese 1999). Equally clear is the fact that this largely court-sponsored Balinese Kakawin tradition that flourished until the late nineteenth century both on Bali itself and in the Balinese courts of western Lombok, owes much to its Java-based forerunner.

The earliest traces of a distinctly Balinese Kakawin tradition date from the second half of the sixteenth century, but only from the late eighteenth century is it possible to identify substantial numbers of Kakawins written in Bali. Although all the extant Kakawins written in Java prior to the fifteenth century, from a period of more than 500 years were preserved in Bali, no contemporaneous works of known Balinese provenance have ever been discovered. Nor do we know whether the major Javanese Kakawins, including the KR, that have survived the journey down through the centuries, circulated in Bali at the time they were written. Rather, the apocryphal tale posits the sudden and panicked flight to Bali of the Javanese Hindu-Buddhist priests and scholars in the face of the spread of Islam in the late fifteenth century, bearing with them their 
centuries-long literary and textual heritage. Balinese historical traditions, including a number of the historical Kidung and genealogical Babad texts, support this version of events. Nonetheless, the sheer scope and scale of the Balinese textual legacy makes this scenario rather improbable.

How, though, are we to account for the appearance of so many Balinese Kakawins after an interval of several hundred years? And how are we to explain their links to earlier Javanese Kakawin traditions? Has every Balinese Kakawin work from the earlier period simply been lost? Can the lack of any tangible evidence for a parallel creative Balinese literary life prior to the sixteenth century simply be attributed to the exigencies of environment and climate or the loss and destruction of court libraries and documents arising from the constant warfare and frequent destruction of court centres that marked Balinese history?

Sheldon Pollock (2006:80) has recently cautioned against making unfounded assumptions that entire bodies of literature and textual knowledge can simply disappear without trace and has argued persuasively for the possibility of the sudden-and spontaneous-emergence of fully-formed literary genres. If we accept that vernacular Balinese genres such as Gaguritan and Babad came into existence at a comparatively late stage in Bali's textual past, probably no earlier than the sixteenth century, then, rather than assuming a widespread total loss of all earlier Balinese Kakawins, should we instead posit the emergence at more or less the same time of an entirely 'new' tradition of Balinese Kakawin composition, the renaissance of a genre fallen into disuse and then revived under court patronage? While this argument certainly opens up the possibility that the Balinese Kakawin tradition represents the independent development of a rediscovered literary form, it cannot entirely explain the extensive preservation of Old Javanese Kakawin literature of a much earlier time from Java, nor the continuities of literary form and thematic concerns in the two abutting Kakawin traditions.

In Java, Kakawin composition survived intense periods of political and social upheaval, although we should not lose sight of the fact that the number of surviving Javanese Kakawin works, just fifteen from a period of more than 500 years, is really very small. Nevertheless, the court-sponsored writing of Kakawins seemingly re-emerged time and time again: first after the shift of the centre of power from Central to East Java in the late tenth century, then again in the wake of the fall of the Kadiri and Singhasari dynasties in the thirteenth century to flourish in the Majapahit era (Hunter 2007b). Even after the end of the Majapahit golden age, it continued until the very end of the 'Indic' Javanese period in late fifteenth century. So too, in Bali, Kakawin continued to thrive 
with remarkable tenacity as the genre par excellence of royal courts in Bali and Lombok until the colonial period at the very end of the nineteenth century.

When we are able to enter the unequivocally Balinese Kakawin world from the eighteenth century onward, we can immediately recognize themes, textual practices and forms evident from earlier periods in Java. Kakawin activity in Bali encompassed both the preservation and study of the Javanese Kakawin legacy and the creation of new works. Many of these Kakawins are virtually indistinguishable from examples composed at the height of the Javanese period. In fact, until more recent studies revealed the extent of Balinese poets' mastery of Kakawin technique, a number of works now known to be of Balinese origin were assumed to have come from Java (see Zoetmulder 1974:382-3).

Whether the Balinese Kakawin tradition represents continuity or revival, there is absolutely no question concerning the influence of the Javanese literary past on Balinese poets. As the examples to be discussed below further attest, Balinese poets relied heavily on the tenth-century Old Javanese prose adaptations of the Sanskrit epics, the Parwas, including the UtK, for thematic source material, while Javanese Kakawins, including the KR, provided models for Kakawin textual practices and poetical conventions. Poets made use of the full range of cultural and literary resources to hand, including their own talents. Even in a genre as bound to poetical convention as Kakawin literature, there was ample scope and, indeed, an imperative for exercising creative genius.

\section{The Old Javanese Rāmāyana Kakawin in Bali}

Before turning to newer compositions, however, we will explore briefly the role and status of the KR itself in Bali. Stuart Robson (1972) has highlighted the importance and popularity of the reading, or rather singing, of excerpts from the Rāmāyana, particularly its didactic passages, in textual mabasan study groups and in ceremonies connected with life-cycle rituals and other religious celebrations. This enduring cultural practice of textual exegesis accomplished through the vocalization of Kawi (Old Javanese) texts and vernacular paraphrasing into Literary Balinese is attested in material form in the extant $R \bar{a}$ màyana manuscripts. The interpreting and performance of texts, first recorded in the tenth-century premiere performance of the Wirätaparwa (Zoetmulder 1974:965-6), remains a significant performance tradition in Bali and is an increasingly popular mass media phenomenon on radio and television (Creese 2009a; Putra 2009).

The Balinese glosses integrated into I Wayan Pamit's four recent Kakawin compositions described above represent a contemporary manifestation of this 
ancient exegetical tradition. Many nineteenth-century palm-leaf manuscripts incorporate interlinear Balinese translations, which as Robson notes (1972:315) are also worthy of an editor's attention as evidence of an interpretation of a work by those who held it to be important at a particular moment in time. Extra-textual information, including these interlinear glosses and details about dating and provenance contained in colophons, provides additional important insights into the significance and function of the KR, particularly in the nineteenth century when the major manuscript collections were formed.

The significance of individual Old Javanese Kakawins has conventionally been judged by the number of available manuscripts. By this measure, the major catalogues of Old Javanese and Balinese manuscripts in Indonesian and European collections-namely Brandes (1901, 1903, 1915:8-27, 1926), Juynboll (1907-11:117-22, 1912), Poerbatjaraka (1933), Pigeaud (1967:176-8, 1968, 1970,1980 ) - bear witness to the ongoing relevance of the KR until the late nineteenth century and beyond in Bali. It is perhaps worth noting that a significant proportion of KR manuscripts are what these catalogues describe as 'fragmentary' texts, that is manuscripts that do not comprise the entire work from sarga 1 to sarga 26, but just a section, sometimes only a very small one, of the Kakawin. Textual fragments of this kind were once dismissed as evidence of lack of diligence or understanding on the part of Balinese scribes and copyists, but we now recognize that what comprises a 'work' in the context of Balinese textual traditions does not necessarily overlap with older European notions of a 'complete' text and that the manifold uses of textual works in traditional Bali is appropriately reflected in the varied nature of physical artefacts, including in such fragmentary texts (see, for example, Vickers 2005:1-14). That so many extant KR manuscripts are indeed fragments, and that many of these fragments include interlinear glosses, is indicative of the day-to-day, practical use on Bali of certain parts of the Old Javanese Rammàyana for specific ceremonial or study purposes. For contemporary lovers of the KR, numerous published editions and Indonesian translations are also now available.

A partial snapshot of the provenance and dissemination of KR manuscripts from the late nineteenth century onwards is provided by the major collections of Balinese manuscripts (see Appendix). It is striking that the extensive Leiden University nineteenth-century collections hold only four complete texts-LOr 2201, LOr 2202 (with interlinear Balinese gloss), LOr 4436 and LOr 4438 (glossed) (Pigeaud 1967:177-8). Of a total of thirty-nine KR manuscripts from the Van der Tuuk Collection ( $\mathrm{Br} \# 890-920)$, only two have the complete text (Bran- 
des 1915:8-27). ${ }^{3}$ Three Rāmāyana manuscripts are found in the Lombok Collection acquired during the Dutch conquest of the Lombok court at Cakranagara in 1894; all are fragmentary texts.

The Kirtya Liefrinck Van der Tuuk Collection (K), established in Singaraja in 1928, has also documented Balinese textual interests, particularly in the colonial period in the first half of the twentieth century, but in a representative rather than comprehensive way. Finally, the more recent and extensive Bali Manuscript Project, the Hooykaas-Ketut Sangka (HKS) Collection established by C.C. Hooykaas in the early 1970s (Hooykaas 1979; Pigeaud 1980:94-6) now contains more than 6000 transcriptions of Balinese texts of every kind and gives a comprehensive view of the Balinese textual legacy in the late twentieth century (Pigeaud 1980; Hinzler 1983, 1993). The HKS collection (Creese 2004a; Witkam 2006-07) has only three transcriptions of the KR, of which one (HKS 3390) comprises the complete text of the Kakawin.

We cannot of course be sure if the representation of KR manuscripts in the Kirtya and HKS collections is indicative of a decline in popularity of the $\mathrm{KR}$ in the twentieth century. Because the works transcribed or copied have been drawn principally from private collections, this relatively small number of manuscripts may instead reflect the special, sacred, nature of this Kakawin or reluctance on the part of the owners of Rámàyana manuscripts to allow them to be copied.

\section{The Rāmāyaṇa 'corpus'}

There is clear evidence of the direct influence of the Old Javanese UtK in later Balinese Rammāyana literary traditions. This influence crosses genre boundaries and is evident not only in the Kakawins discussed here but also in prose works and in Kidung and Gaguritan poetry. A comprehensive, although by no means exhaustive, survey of the extant Balinese manuscript corpus reveals a range of Kakawins that draw on broader Rámàyana themes. Although the Old Javanese KR might be considered to occupy a special place in Balinese $R \bar{a}$ màyana traditions, it is striking that the core KR story-the marriage of Rāma and Sìtā, Rāwaṇa's abduction of Sìtā and her subsequent rescue, Rāma's attack on Lĕngka with the assistance of Hanuman's monkey army and the defeat of Rāwana-does not appear to have provided sustained thematic inspiration, or at least not for Balinese Kakawin poets. Instead, most of these Balinese Kakawin

3. Two of the thirty-nine Ràmāyaṇa manuscripts in the Van der Tuuk collection listed in Brandes' catalogue (Brandes 1915:8-27; Br \#890-920), namely Br \#902 = LOr 3899 (5) and $\mathrm{Br} \# 903$ $=$ LOr 3878 (2) are missing from Pigeaud's summary list (1967:177-8). 
works draw thematically on the UtK, and take as their heroes such figures as Aja, Arjuna Sahasrabāhu and Rāmaparaśu or anti-heroes such as Rāwaṇa and his descendants. These wide-ranging thematic interests demand in turn a broad definition of works that might be considered to belong to the Rammayana 'corpus' of Balinese Kakawins.

Deep and wide-ranging interest in the vast mythical, genealogical and narrative repertoire of Sanskrit epic traditions is already evident in the Javanese period where it found expression in numerous literary works and in temple reliefs, as the chapters in this volume attest. As in Bali in later times, a number of the East Javanese Kakawins focus on characters and events drawn from the far reaches of the epic traditions or from Sanskrit Kāvya literature more generally. Examples abound: the burning of the ill-fated god of love in the Smaradahana, Kṛṣna’s military and sexual conquests in the Hariwangśa and Kṛșnayyana, the exploits of minor heroes such as Ghațotkaca in the Ghațotkacāśraya and Bhoma in the Bhomanntaka. More directly connected to the Rāma cycle are Javanese Kakawins such as the Sumanasäntaka, in which Mpu Monaguna relates an ancestral story which tells of the tragic death of Indumati, the wife of Aja, scion of the lineage of Raghu, father of Daśaratha and grandfather of Rāma, and the Arjunawijaya, which centres on an episode from the UtK, namely the defeat of Rāwaṇa by Arjuna Sahasrabāhu.

In his discussion of the Arjunawijaya in Kalangwan, Zoetmulder (1974:400) suggested that there was insufficient evidence to determine whether Mpu Tantular drew on the Old Javanese UtK. Any uncertainty was laid to rest by the subsequent publication of Supomo's edition of the Arjunawijaya (1977) with its detailed analysis of the relationship between the Kakawin and the Old Javanese UtK. Supomo (1977:16-26) showed that although Tantular might have drawn on a number of sources, there was no question that he also derived materials for his Kakawin directly from the Old Javanese UtK. Interestingly, it seems that just as in the case of the KR itself, closer textual dependence is found in the first part of the poem (cantos 1-19) with a freer treatment of UtK themes in the remainder of the poem.

The figure of Arjuna Sahasrabāhu is an intriguing one. In the Javanese period, he occurs only in the accounts of his conflict with Rāwana in the Arjunawijaya and UtK, but he emerges as a central figure both in Javanese wayang and in later literary traditions in the golden age of literary activity in Surakarta in the eighteenth and nineteenth centuries (Zoetmulder 1974:403-4). ${ }^{4}$ As we

4. See also the discussion below (p. 111) concerning the possible dating of the Ramawijaya to the early Majapahit period. 
will see, his exploits are also recounted in a number of works from Bali.

All the Balinese Kakawins that embrace Rāmàyana themes draw in some measure on the UtK. Even in a genre as bound to poetical convention as Kakawin literature, there was ample scope and, indeed, an imperative for exercising creative talent and for expanding the concise prose text into a long poetical work. On the basis of its treatment of the subject matter, and its language and style, the Old Javanese UtK is believed to have been composed at roughly the same time as the Parwas of the Mahābhārata, that is, in tenth-century East Java (Zoetmulder 1974:83). Centuries later, these ancient Old Javanese prose works, including the UtK, functioned as the principal source for Balinese Kakawin poets. The prominence of the UtK is further attested by the more than twenty extant manuscripts of this text in the manuscript collections.

The Balinese Kakawins belonging to the Rammayana-UtK epic cycle discussed below can be divided into two groups on the basis of their thematic concerns. The first group comprises works that revolve around a number of satellite stories from the UtK, principally related in Agastya's account to Rāma of Rāwaṇa's history prior to the events described in the KR, or from events that take place in the final stages of Rāma's reign and life. The second group of Kakawins expands on the figure of a single UtK hero, Arjuna Sahasrabāhu, whose defeat of Rāwana narrated in sargas 18-19 is the subject of Mpu Tantular's fourteenthcentury Kakawin, the Arjunawijaya.

By the end of the nineteenth century, almost the entire UtK had been transposed into Kakawin verse. In fact, there seems to have been what might be called a 'Kakawin-writing project' to versify the seventh and final kānda of Vâlmiki's epic, at least if we include here, for the sake of completeness, the Arjunawijaya - which to judge by the number of Balinese manuscripts dating from the eighteenth and nineteenth centuries (Supomo 1977:83-8, 178-9) was a well-known and popular work in Bali in this period.

The UtK 'Kakawin project' begins with the Hariśraya (sargas 5-8), continues with the Arjunawijaya (sargas 8-19a) and the Indrabandhana (sargas 19b29), and ends with the Ramakanda (sargas 38-67). The only missing section in the sequence is the episode that immediately follows Agastya's narration of the early history of Rāwana to Rāma (sargas 30-37). At this point, the text resumes the story of the core figures of the KR, dealing with the period of Sitās exile, when Rāma, now re-established in Ayodhyā, responds to the rumours circulating in the city that question Sîtā's fidelity while held captive by Rāwana in Lěngka, and sends his pregnant wife away to live in the forest. As we noted earlier, in the world of the Balinese Kakawin poet, the core Rāma-Sìtā story seems 
to have been 'off-limits'; perhaps no poet dared to consider his talents adequate to the task of recreating the Âdi-Kakawin. The same may have been true for this final episode in the Rāma-Sìtā story related in the UtK.

Below, I describe each of the Balinese Kakawin works belonging to this extended Ràmāyana-UtK 'corpus' and trace their thematic concerns, comment on their dating and provenance where possible, and explore their intricate and varied intertextual links. The Kakawins can be ordered chronologically, if somewhat tentatively, according to the time in which they entered the manuscript collections. ${ }^{5}$ Occasionally more reliable dating information is available for individual works. A summary list of the works to be discussed is provided in the Appendix.

\section{Uttarakānda myths and stories}

\section{Hariśraya A and Hariśraya B ('Hari’s Succour')}

Based on sargas 5-8 of the UtK, the Hariśraya deals with events prior to the birth of Rāwana, namely the battle between the gods and the demon kings of Lĕngka in which Wiṣnu defeats the three demon brothers, Mālyawān, Māli and (Rāwana's father) Sumāli. There are two versions of the Hariśraya, a short version, the Hariśraya A comprising 198 stanzas in 20 cantos and a long version, the Hariśraya B with 304 stanzas in 53 cantos. $^{6}$ A summary and the introductory stanzas and epilogues of each version are given in Zoetmulder (1974:401, 497). The Hariśraya A has been edited and translated into English by Wulan-

5. Where no more specific information on dating or provenance is available, works registered in the Van der Tuuk Collection (Pigeaud 1967:177-8), have a terminus ante quem of 1896, while those in the Lombok Collection date from the time prior to the sacking of the royal palace of Cakranagara by the Dutch in 1894 (Pigeaud 1968:5-6). For the twentieth century, the situation is more complex since both the Kirtya Collection and HKS Collection comprise transliterated copies of original palm-leaf manuscripts borrowed from private collections all over Bali and Western Lombok. Many Balinese works were recorded for the first time in the Kirtya Collection, but the Kirtya records provide little specific information about ownership or provenance, and thus are of limited usefulness for dating purposes. The Kirtya transcriptions made during the years immediately following its establishment in 1928 can be tracked in stages through the lists that were published at regular intervals between 1929 and 1935 in the Mededelingen Kirtya Liefrinck Van der Tuuk. The HKS Collection comprises transcriptions of manuscripts copied mainly between 1972 and 2002. The manuscripts transcribed for the Kirtya and HKS Collections frequently have much earlier origins, and the individual transcriptions sometimes provide valuable information about the ownership and provenance of the manuscript concerned.

6. The designations A and B are those assigned to each version by Van der Tuuk and incorporated into Brandes' (1903:17-22) and subsequent catalogues. 
dari (2001; see also Jákl 2008). The Hariśraya B has not yet been edited or studied in detail. Zoetmulder (1974:401) concludes that the two versions are by different hands but are similar in terms of language and verse technique. Nevertheless, in the light of the more extensive research into the Balinese Kakawin tradition since the publication of Zoetmulder's invaluable survey that has led to a reassessment of the facility of Balinese poets in composing Kakawins in Old Javanese until recent times, we should be very cautious about assessments of intertextuality and relative dating that are based on linguistic and stylistic features. The relationship between the two versions of the Hariśraya remains unclear. They appear to be independent renditions of the same story taken from the UtK, in contrast to other known examples from the Balinese Kakawin repertoire of interdependent recensions of the same work, including the Pārthāyana/Subhadrāwiwāha (Creese 1981, 1998:85-140), the Āstikāśraya A and B and the Krṣnāndhaka A and B (Zoetmulder 1974:395; Creese 1998:857). A detailed study of both versions of the Hariśraya would be needed to determine the exact nature of their interrelationships.

We do, however, know a little about their dating. The Hariśraya A is known from two copies both transcriptions in Balinese script of original lontar manuscripts from the Van der Tuuk collection, LOr 4234 and LOr 3888 (Pigeaud 1967:190-1) and two transcriptions from the Kirtya and HKS Collections (K $635=$ HKS 1864). LOr 3888 has a brief colophon, referring to a time of destruction that incorporates dating elements which Damais (1958:213) has calculated as equivalent to Friday, 30 January $1891 .^{7}$ The dating of this copy of the text provides a terminus ante quem of 1891 for the Hariśraya A. There seems little question that this Kakawin is of Balinese provenance. It displays a number of characteristic features which we might consider to be a hallmark of nineteenth-century Balinese Kakawin composition. The introductory hymn of devotion begins with the customary phrase used before the invocation of the name of the tutelary deity, the great priests or the master poets: 'I bow down in homage at the feet of ...' (sěmbah ni nghulun ring jöng ...). ${ }^{8}$ In this case, the

7. The description of the Hariśraya in Creese (1999:77) contains some inaccuracies. The number of stanzas originally reported in Zoetmulder (1974:557) and repeated in Creese for the $\mathrm{Ha}$ riśraya A and Hariśraya B versions, 195 and 297 stanzas respectively, was incorrect. The information has been revised by Wulandari (2001:2). LOr 15.008 (= K 635; HKS 1864) has been erroneously listed as a manuscript of the Hariśraya B. It is actually a copy of the Hariśraya A. The śaka year 1812 given in the colophon corresponds to the period from March 1890 to February 1891 , not 1900 .

8. This formulaic expression occurs in the Nìtiśāstra, Āstikāyana, Wṛtāntaka, Pārthawijaya (Irawāntaka), Indrabandhana, Bhārgawaśikșā, Dharmakusuma, Si Wṛta, and Parikșit, as well 
poem is offered to Saraswatī, goddess of learning, a prominent deity in Balinese Kakawin from the nineteenth century (Zoetmulder 1974:174; Wulandari 2001:7-8). The poem ends with the short, one-stanza, self-deprecatory epilogue typical of Balinese poets.

The situation with regard to the Hariśraya $\mathrm{B}$ is less clear cut. The third stanza of the introductory invocation contains a hidden chronogram giving the time and place of composition as 'six-nine-water-moon' (sad sangañjala candra), a year equivalent to 1496 śaka (1574 AD) in Lāwanādipura. ${ }^{9}$ Because the events related in the Hariśraya B immediately precede those detailed in the Arjunawijaya, Supomo (1977:10-5) suggested that the two works may have been contemporaneous and argued, somewhat tentatively, that if the reading of añjala (water $=4$ ) were emended to añjali (sěmbah $=2$ ), the chronogram of the Hariśraya B might be read instead as 1296 śaka or $1374 \mathrm{AD}$ and the text would thus be dated to the Majapahit period. ${ }^{10}$

As I have argued elsewhere (Creese 1998:86-7, 1999:53), there is no reason not to accept the chronogram at face value since Lāwanādipura can equally be read as a synonym of Amlapura, that is, of Karangasem, East Bali. If this interpretation is valid, then the Hariśraya B is the earliest known Balinese Kakawin.

Both available manuscripts have additional colophons indicating that more copies of the work were being made in the late nineteenth century. The colophon in LOr 4235 (Brandes 1903:22) breaks off abruptly so that the reading is not entirely clear but indicates that 'the time of writing was Sunday, Kliwon in the week Julungwangi, on the 13th day of the dark half of the moon in the first month of the year, 3 units 3 tens' (dinānrat, $a, k a$, wara julungwangi, pang, ping, 3, wlas, śaśih, 1, rah 3, tĕnggĕk 3). Damais (1958) does not include this

as in a closely synonymous phrasing in the Khäṇawawanadahana, Ratnawijaya, Kṛ̦nāntaka, Ràmaparaśuwijaya and Pārthakarma (see Zoetmulder 1974:486-505).

9. Hariśraya B 1.3 (Zoetmulder 1974:498):

Nghing pinantangkwa ri sang wĕnang sunga wĕnangkwīki n sakahyun mami

mwang sang wruh pwa ri bhāṣa towi hana ring sunggutnya chandakrama

lwir māsung wibhawe nghulun hid̆ĕp iki n singgih kawīndreng dangu

sad sangañjala candra käla winangun ring Läwanādipura.

10. Until recently, we were forced to rely on a single manuscript for the text of the Hariśraya B, namely Van der Tuuk's autograph transcription in Latin characters (LOr 4235), so a margin for error is certainly possible. A second copy of this Kakawin, however, has now come to light in the HKS Collection (HKS $3184=$ LOr 16.328). This transcription provides a slightly different reading of the chronogram in question (sad sang añcala candra-six-nine-mountain-moon) that provides a reading of 7 for the hundreds since $(a(n)$ cala or acala 'mountain' has a value of 7 . The chronogram year is thus equivalent to the śaka year 1796 or $1874 \mathrm{AD}$. This reading would point very clearly to a Balinese origin for the Hariśraya $\mathrm{B}$, although a much later one than the sixteenth century one indicated in the chronogram in LOr 4235. 
manuscript in his list of dated manuscripts from Bali, indicating that not all of the dating elements (the days of the seven-day and five-day week, the Balinese month (wuku), the phase of the moon and śaka year) could be reconciled. ${ }^{11}$ The year' 33 śaka included in this dating is equivalent to the year' $11 \mathrm{AD}$. At the very least, the colophon suggests a terminus ante quem of 1811 for the Van der Tuuk copy of the Hariśraya B.

The colophon of HKS 3184 identifies the text somewhat misleadingly as the story of the Arjunawijaya from the Uttarakanda. It indicates that the year of copying was ' 11 śaka or ' 89 AD. ${ }^{12}$ Since the transcription entered the HKS collection in February 1981, it cannot refer to 1989 and the colophon itself must date back to at least the nineteenth century, $1890 \mathrm{AD}$; the use of the Indonesian 'Kamis' to indicate the day of the seven-day week, however, points to a recent date or editorial change.

There is little further evidence to allow us to date the Hariśraya B with greater accuracy. There are, nevertheless, other clues that point to Balinese provenance for the Hariśraya B. In the epilogue (53.2), where we learn that the title of the work is Hariśraya, the unnamed poet observes that, whereas once poets roamed the mountains and seashore, he is composing his poem in the midst of the battle field as he marches against the enemy carrying a bow as his karas (writing board) and arrows as his tanah (stylus). The allegorical aptness of the theme of the poem and a military campaign is obvious. Moreover, in Balinese manuscript traditions there are frequent direct links made between textual activity, particularly the copying of appropriate texts, and times of war and destruction throughout the eighteenth and nineteenth centuries (Vickers 1990; Creese 1996, 2009c). The almost constant interkingdom rivalries and armed skirmishes in precolonial Bali provided ample opportunities for a poet to accompany his royal master into battle. Finally, its place as one literary work in the larger UtK-derived Rāmàyana corpus from Bali proposed here perhaps lends further support to its Balinese heritage.

As we have already noted, the following sections of the UtK (sargas 9-19) detailing the defeat of Rāwaṇa by Arjuna Sahasrabāhu are taken up by Tantular in the Arjunawijaya (Supomo 1977). The Balinese Kakawin tradition then provides two Kakawins to bring the retelling of the prose work to completion in

11. For a recent overview of the challenges for interpreting dates in Balinese texts, see Proudfoot 2007.

12. Iti Ari Sraya samapta pinrakreta prangi Arjuna Wijaya ri Utarakandha. ом Saraswattye namah, oм GMUNG Ganapataye namah, oм Sri Gurubhyo namah. Kunang prasta tinurun, kalan ing dalu, ri makara cala, ring aramptra, banjar kilara, duki waya, kmis, wisnu, hretiya kresna, masa posya, sonita mwang tandha samasatu, wara, watek. 
Kakawin-verse form. These two works are the Indrabandhana and Rāmakānda (or Śatrughna).

\section{Indrabandhana ('Indra Bound')}

The Indrabandhana continues the story of the UtK from the point at which the Arjunawijaya finishes with the release of Rāwana. The poet describes a series of battles between Rāwaña and his enemies (Zoetmulder 1974:400-1). The poem takes its name from the final episode (19.4-26.21), which concerns the war against the gods when Indra is captured by Rāwana's son Meghanāda. For this feat, he is given the name Indrajit, 'victor over Indra'. There is a close parallel with the prose text to the end of sarga 29 which completes Agastya's account of Rāwana's history. Zoetmulder (1974:400) observes that the language suggests it is of recent date, but that 'its verse technique is almost faultless'. There are several copies of this work, two of which indicate the year of copying as 1905 (CB 55) and 1911 (K 688) respectively (see Appendix). The Indrabandhana must therefore date from no later than the beginning of the twentieth century.

\section{Rāmakāṇda (Śatrughna, Rāmayajña, Sang Hyang Śry Ātmaśuddha)}

The final part of the UtK provides the framework for the events related in the Rāmakān da from the episode concerning the expedition of Rāma's brother, Śatrughna, against the demon Lawana in sarga 38 (Śatrughnaprāyana) until Rāma's ascent to heaven (Swargärohana) at the end of the text in sarga 67 (Zoetmulder 1974:402, 498). Although it is by no means unusual for works to be known by a variety of titles in Balinese manuscript traditions, this work has an unusually large array of titles and is also known as Śatrughna, Rämayajña and Sang Hyang Śry Ātmaśuddha.

Although these titles are cross-referenced in the index to Pigeaud's supplementary catalogue $(1980: 109,162,194,229)$, their intertextual relationships are not apparent from the individual entries. A closer reading of the manuscripts, however, confirms that they are all transcriptions of the same work (see Appendix).

The Kakawin runs in close parallel with the Old Javanese prose text. Zoetmulder (1974:402) notes that 'the Kakawin and the prose Uttarakānda are so alike, even in their vocabulary, as to allow me to use the Kakawin for correcting faulty readings in my copy of the prose work', but this statement perhaps underrates the creative skills of the poet. While it is true that core phrases have been taken from the prose text and in the order in which they occur there, the work 
is far more than a simple versification of the prose text. This Kakawin contains the usual mixture of digressions on the natural world, long battle scenes and the full array of other poetic requirements for which the unnamed poet's succinct prose model would have provided little assistance.

The poet notes that he is creating his poem from the 'eighth kanda' of the Ràmanyana. He dedicates his Kakawin to the eminent ascetic (yatìwara), possibly Wālmiki, who is said to be like the great lotus (mahäpadma) of which the eight kāndas (astakānda) form the petals. Zoetmulder (1974:402) suggests that this apparent deviation from the seven kāndas of Sanskrit Rāmāyana tradition may arise from conflation with the analogy in the poet's dedication to the eight-petalled lotus. He argues that the reference to the eighth kanda probably signals the last part of the UtK where the story of Rāma continues, a suggestion borne out by the name Rammatantra given to the poem in this stanza (Zoetmulder 1974:498-9). There is no evidence to indicate that a division into eight $k a \bar{n}$ dqas represents any kind of wider Balinese tradition, and it must therefore be regarded as an idiosyncratic (mis-)understanding of the poet himself.

There is a considerable number of copies of this Kakawin, which first came to light in the Kirtya Collection (K 628) with a transcription of a lontar of fiftyfive leaves originating from the collection of Gusti Putu Jlantik, the foundation curator of the Kirtya Collection. This manuscript has a colophon mentioning a scribe in Cakranagara Lombok in 1846 śaka/1924 AD (Pigeaud 1968:766) and was part of a group of texts acquired by Jlantik from Lombok at that time. The work may date from the mid nineteenth century since the epilogue appears to contain a chronogram referring to the third month (katiga māsa) in the year 'body-eight-mountain-moon', awak (1) asta (8) ning hacala (7) candra (1), equivalent to 1781 śaka or 1859 AD. ${ }^{13}$

\section{Kakawin Rāwana}

I Wayan Pamit's contemporary Kakawin, the Kakawin Rāwaṇa, also deserves a mention here. The first part of the work relates the stories of Rāwana's birth, life and battles against the gods before his encounter with Rāma as set out in sargas 1-18 of the UtK. It includes the events related in the Arjunawijaya, such as his encounters with the female ascetic Wedawati and his capture by Arjuna

13. The text reads: āpan tan hana ramya ning katiga mäsa rumacana <pa>lambing ing karas / medran mānawak asta ning acala candra nika madangi kāla ning kulěm (Zoetmulder 1974:499). The interpretation of the date is not altogether clear. If the value of the units is not read as awak (body $=1$ ) but as manawak 'to call out, request' and thus related to speech, which has a value of 6 , this would give the year 1786 śaka or 1864 AD. 
Sahasrabāhu. In addition, it relates the core KR narrative from Rāwaṇa's abduction of Sìtā to the destruction of Lĕngka and his defeat by Rāma. The poem ends with Rāwana's death. The contemporary character of this Kakawin is perhaps revealed in the poet's comprehensive treatment of the entire Rāma-Rāwana story in a single work.

\section{Two Rāmas, two Arjunas: Balinese Kakawin based in wider epic traditions}

In the epilogue of the Arjunawijaya, the poet Tantular dedicates his poem to Wiṣnu at whose hand in former incarnations both Rāwaṇa (Daśamukha) and Arjuna Sahasrabāhu have met their fate in battle. As Zoetmulder (1974:344) notes these two references allude to two distinct Rāmas: Rāma, son of Daśaratha, the hero of the KR who defeated Rāwaṇa, and Rāma Bhārgawa or Paraśurāma ('Rāma with the Axe'), the slayer of Arjuna Sahasrabāhu. The first of these deaths is the one recounted in the core story of the KR; the second is the death of Arjuna Sahasrabāhu in his battle against Rāma Bhārgawa. There are two Arjuna's and this Arjuna recast as the hero of Tantular's poem is not, of course, the more well-known Mahābhārata epic hero, Arjuna Pāṇạawa. In the UtK and in the Arjunawijaya, Arjuna Sahasrabāhu proves himself capable of conquering Rāwaña, the sworn enemy of the exemplary hero Rāma; in his confrontation with Rāma Bhārgawa, however, Arjuna Sahasrabāhu has now become the enemy of those seeking to maintain the world order. Arjuna Sahasrabāhu, who is also a prominent figure in later Javanese literary and wayang traditions, appears to have captured the imagination of Balinese poets. His confrontation with his nemesis Rāma Bhārgawa is recorded in two Kakawins, the Rāmaparaśuwijaya ('The Victory of Rāmaparaśu') and the Rāmawijaya ('The Victory of Rāma').

These epic heroes, Rāma and Arjuna, twinned incarnations of Wiṣnu with their parallel names, underpin the fundamental intersections between the different branches of epic tradition that are evident in Java in the fourteenth century and continue into the later Balinese period of Old Javanese literature. In Sanskrit literature too, both Rāma Bhārgawa and Arjuna Sahasrabāhu find a place in each of the core epic traditions. In the Mahäbhārata, Rāma Bhārgawa figures as the warrior-ascetic who vows to annihilate the ksatriya race to avenge the death of his father, Jamadagni at the hands of the sons of Arjuna Sahasrabāhu. The Mahābhārata relates the story of the combat between Rāma Bhärgawa and Arjuna twice, once in the third book, the Äranyakaparvan, the Book of the Forest (3.115-117), and again in the twelfth book the Siantiparvan (12.49) when Kṛṣna is relating the ancestral tale to Yudhișthira (Brockington 1998:283-6; Van Buitenen 1973). The catalyst for the conflict that results in 
the death of Arjuna Sahasrabāhu and sets off the train of events in which Rāma Bhārgawa slaughters the kșatriyas and fills the five lakes (pañcatìrtha) with their blood, differs somewhat. The Santiparvan version is believed to be a secondary retelling of the Äranyakaparvan (Brockington 1998:284).

Rāma Bhārgawa also makes a brief appearance in the Old Javanese KR in sarga 2, where he encounters Rāma returning to Ayodhyā after his marriage to Sìtā and challenges him to a contest to bend his bow. Rāma accomplishes this feat with such ease that Rāma Bhārgawa goes away in perplexity. Rāma Bhārgawa is also a central character in the Ambāśraya ('Ambā seeks Succour'), a Balinese Kakawin derived from the Mahābhärata traditions as related in the Udyogaparwa. This time it is Bhișma who is challenged to combat by the seer. The gods, alarmed by the potentially dangerous outcome of this encounter, intervene and Rāma Bhārgawa is forced to accept defeat. All the available manuscripts of the Old Javanese Udyogaparwa end abruptly and the sections dealing with this episode in the Old Javanese Udyogaparwa are missing. Therefore, it is no longer possible to ascertain if the inclusion of the quarrel between Bhịsma and Rāma Bhārgawa in the Ambāśraya relates to the earlier Old Javanese Parwa or even KR tradition or is a specifically Balinese adaptation of the Sanskrit epic tale (Zoetmulder 1974:74, 400).

Rāma Bhārgawa appears to have been a prominent figure more widely in Balinese religion and philosophy. Teachings ascribed to him are contained in the Bhārgawaśikṣā ('The Teachings of Bhārgawa'), a didactic Kakawin detailing the imminent destruction of the world as a result of human misdeeds and immorality. He is also cited in Balinese law codes as a source of wisdom and guidance (Creese 2009b:266). Zoetmulder (1974:400) suggests that he may have had strong appeal to the Balinese brahmanical caste and links him to the Supreme Teacher (parameșthiguru) to whom the Bhärgawaśikșā itself is dedicated in homage, as well as to the unidentified sage or teacher referred to frequently in the introductory stanzas of a number of Balinese Kakawins including the Khändawawanadahana, Irawāntaka, Indrabandhana and Si Wrta (Zoetmulder 1974:174). ${ }^{14}$

In the two Kakawins discussed here, there are wide deviations from Sanskrit traditions relating to the episode detailing the battle between Rāma Bhārgawa and Arjuna Sahasrabāhu. These divergences reflect the processes of adaptation that are characteristic of Old Javanese literature as a whole, and also raise interesting questions about the poets' sources. Only eight of the eighteen books

14. For the discussion of the possible connection between Bhärgawaśikṣā and the Old Javanese Kuțāramānawa law code, see Creese 2009b. 
of the Mahābhärata are found in Old Javanese renderings. On the basis of the extant Old Javanese sections of the epic, Zoetmulder (1974:98-100) has proposed that the Parwas, up to and including the sixth book, the Bhissmaparwa, may have formed part of a comprehensive 'project' intended to encompass the entire epic which for some reason was then discontinued, and further that the third of these six parts, the Wanaparwa later disappeared. As evidence for his argument that an Old Javanese Wanaparwa may once have existed, Zoetmulder suggests that it might have been expected 'to have a special appeal because of the variety and colourfulness of its stories', and because of the fact that one of the most well-known East Javanese Kakawins, the Arjunawiwāha, derives from an episode related in this third Parwa. ${ }^{15}$ In the Sanskrit Mahābhārata, the episode of Rāma Bhārgawa's defeat of Arjuna Sahasrabāhu is found in the Wanaparwa, and the two Kakawins discussed below dealing with this Rāma Bhārgawa-Arjuna Sahasrabāhu episode may also point to local knowledge of the Wanaparwa in the Archipelago for which no direct textual traces remain.

In spite of their thematic similarities these two Kakawins, the Ramaparaśuwijaya and the Rāmawijaya are independent works. There is no question of direct interdependence since the two works treat their common theme quite differently. There is even a possibility that these two works may in fact be separated geographically and temporally as we will explore in more detail below.

\section{Rāmawijaya ('Rāma’s Victory') or Arjunāntaka ('The Death of Arjuna') ${ }^{16}$}

The Rämawijaya commences with lengthy descriptions of the splendours of the kingdom and the palace, the delights of the love-making between Arjuna Sahasrabāhu and his wife (who is not named), and the beauties of nature they encounter as they undertake their pleasure trip with their full entourage of followers. They encounter Nārada who warns Arjuna of the power of Rāmaparaśu.

15. There is another Kakawin registered under the title of Aranyakaparwa in the Rotterdam Museum (RtMLV 28857; Pigeaud 1968:862) which appears to have the Wanaparwa as its source. LOr 10.757 contains a transcription made in 1940 by Soegiarto for the University of Leiden. The text finishes abruptly at canto 26.5. The poem deals with the fate of the Panndawas after the loss of their kingdom to the Korawas in the game of dice.

16. Pigeaud (1967:184) includes cod. 4697 (= BCB portfolio 23 and 164) in his major Kakawin group A, and describes it as a work entitled Arjuna Sahasra Bāhu: 'An unknown twelfth century Kadiri Court poet wrote a poem on the struggle of the epic heroes Arjuna Sahasra Bāhu also called Karta Wirya, and Rāma Bhārgawa (Paraśu Rāma, Jāmadagnya). The greater part including the conclusion of the poem is missing in the only available manuscript. Interrelationship of the twelfth century fragmentary Arjuna Sahasra Bāhu Kakawin and the fourteenth century Arjuna Wijaya by the Majapahit Court poet Tantular [...] is as yet unproven'. 
Arjuna then vows to seek him out and defeat him in combat. Further scenic descriptions, episodes of love making and a detailed account of preparations for the battle follow. The poet then provides a lengthy account of the war and the combat between Rāma and Arjuna Sahasrabāhu that results in the latter's death. The final section of the poem contains a vivid account, of the sati death of Arjuna's wife on the battle field, where she stabs herself with her kris in order to join her beloved in heaven, which is reminiscent of similar descriptions of sati found in many Kakawins from both Java and Bali (Creese 2004b:210-23).

Initially, I had classified the Rāmawijaya as a hitherto undescribed Balinese Kakawin, but that conclusion has turned out to be an open question in need of further investigation. Although the Kakawin ends with a lengthy colophon that appears to locate it in the Balinese tradition, closer inspection of the text reveals that the Rammawijaya may instead be of late thirteenth-century East Javanese origin, dating from the time of the transition from Singhasari to Majapahit political and cultural hegemony, a period from which no other Kakawins survive.

The Van der Tuuk Collection holds a 'fragmentary' text in 40 cantos described along with other untitled Balinese Kakawin works by Brandes in the fourth volume of his catalogue (Brandes 1926:3-6; Br 1461 = LOr 4697). Comprising 42 pages in Balinese script, LOr 4697 is a copy of a lontar of 25 leaves belonging to 'Dalang Gĕde Rĕněh di Sung (?)'. As Soegiarto noted in his later transcription of Van der Tuuk's manuscript (BCB 23; BCB 164 [5]), the actual content of the Leiden manuscript is the description of a pleasure trip undertaken by Arjuna and his wife. Brandes, however, had already hinted in the early twentieth century that some sections of this manuscript may have been missing. He drew attention to a hand-written note on the manuscript by Van der Tuuk noting that this poem may have been written 'under Kāmeśwara of Kadiri' and that it concerned 'the battle between Arjuna Sahasrabāhu and Rāma Bhārgawa' (Kĕkawin gedicht onder Kāmeśwara (?) van Kaḍiri (Ardjuna Sasrabahu’s strijd met Rāmaparaśu)). Brandes (1926:6) suggested that Van der Tuuk's complete manuscript must have dealt with the combat of Rāma Bhārgawa and Arjuna Sahasrabāhu, and thus that Arjunāntaka ('The Death of Arjuna') would be an apposite title, a speculation that later found its way into Pigeaud's (1967) catalogue. ${ }^{17}$ Not surprisingly, this incomplete', fragmentary Kakawin has been accorded no further attention.

17. Juynboll (1907-11:180) gives no title, but describes it as 'pure' (zuiver) Old Javanese and notes it has more of a descriptive than epic character. Pigeaud (1967:184, 1968:242, 793, 806) gives it the title Arjuna Sahasra Bāhu and ascribes it to an unknown Kadiri poet. The poem is cross-referenced as Arjunāntaka in the index (Pigeaud 1970, s.v.). 
Nevertheless, Van der Tuuk's marginal note points to the fact that the text from which he was working included additional cantos describing the battle as well. For some reason, either the copying of the text came to a halt at canto 40 , midway through the copying process, or pages were subsequently lost and this incomplete manuscript then passed into the Leiden collection. More than a century later, it has now been possible to recover the complete text, thanks to the HKS Collection where the entire Kakawin of 766 stanzas in 107 cantos, is found under the title of Ramawijaya as HKS 4/30. Moreover, the introductory eulogy and epilogue to this poem contain considerable information about the patron and poet, Taningrat ('Not of this World'), who clearly identifies the title of his work as Rāmawijaya, 'The Victory of Rāma.' ${ }^{1}$

\section{Rāmaparaśuwijaya}

There is little doubt about the Balinese origins in the case of the Rāmaparaśuwijaya, the second Kakawin that takes as its theme the Rāma Bhārgawa and Arjuna Sahasrabāhu story. The poem has two loosely-connected episodes. It begins with the story of two star-crossed lovers, the heavenly nymph, Renuka, and the apsara king, Anggaraparna. Renuka has been locked up in Indra's palace and Anggaraparna wanders the mountains in lovelorn misery before seeking the help of his friend Arjuna Sahasrabāhu in rescuing her. Indra, apprehensive about the outcome of the looming battle, enlists the aid of the Brahmin, Jamadagni, and persuades him to take Renuka as his wife. She provides him with a son, Rāma Bhārgawa. Nārada, ever-ready to shape the destiny of the world, advises Arjuna Sahasrabāhu of the might of Rāma Bhārgawa. Arjuna, who here is known by his name of Kārtawira, sets off immediately to confront his foe. The Renuka-Anggaraparna subplot, however, remains unresolved, although there is a brief interlude in the midst of Arjuna's battle preparations when the lovers do meet once again secretly and escape to a secluded spot. At this point the two different Kakawin versions converge. Arjuna Sahasrabāhu marches out with his armies and his many allies but, with Indra's aid, Rāma Bhārgawa kills all the tributary kings in the ensuing battle. Arjuna finally assumes his divine form as Rudra but is defeated by Rāma Bhārgawa, who manifests himself in the form of Wiṣnu. Arjuna returns to heaven and his wife, Citrawatī, follows him in death. The ksatriyas are completely annihilated and their blood turns into the

18. Since its place in the Balinese tradition now seems less certain, further discussion of the provenance and dating of the text, including its possible relationship to the Ràmaparaśuwijaya must be left for another occasion. 
five bathing places (pañcakatìrtha) possessed of extraordinary purifying powers.

The Ràmaparaśuwijaya appears to be of nineteenth-century Balinese origin. One copy of the text from the Van der Tuuk Collection, LOr 3887 (also 1967:197), has a colophon which Damais (1958:238) has dated precisely to Sunday, 1 March 1891. This date provides a terminus ante quem for the work. The time of composition, however, is not known. Zoetmulder (1974:402-4), who provides a summary, notes that this work displays stylistic similarities with a number of other eighteenth and nineteenth-century Balinese Kakawins such as Subhadrawiwāha, Hariwijaya and Abhimanyuwiwäha. Nevertheless, this work also reflects the legacy of poetic conventions of Javanese Kakawins. For example, the pleasure trip is reminiscent of the Rammayana, and there are obvious and very close thematic and structural parallels with the Arjunawijaya. We have sufficient evidence of the close study of Javanese Kakawins in Bali for these parallels to be unremarkable but the Rāmaparaśuwijaya remains a literary work worthy of closer consideration.

\section{Sumantri (Mahispati)}

Another Kakawin that belongs to the Arjuna Sahasrabāhu cycle is the Sumantri. Zoetmulder (1974:402), who makes only a single reference in passing to this Kakawin, describes it as 'an endlessly protracted work of no literary value that hardly deserves the name Old Javanese.' In the introduction to the poem, the poet explains that he wishes to tell a Parwa story from his desire to hear of the true nature of the UtK, so that clear insight might be imparted and, further, that he wishes to tell the story of Arjuna Sahasrabāhu. In the epilogue, he reveals that the story he has just related was commissioned by he who rules on the boundary of Amla.' ${ }^{19}$ This reference indicates the Sumantri is a work of Karangasem provenance originating from East Bali or from the Balinese kingdoms of western Lombok.

But is there only one Sumantri? The Sumantri, whose introductory verses and epilogue are included in Zoetmulder's appendix in Kalangwan (1974:500), is a different work from the one bearing the same title found in two transcrip-

19. The interpretation is not altogether certain. The text reads (ndah sāmangkē hingan ikang kathā wiwakșan, de sang arājya ri pagěr nagāra Amla, de sang arājya ri pagěr nagāra Amla, ndātan len patra nira manggalāsing ahyun). The repetition of the second line suggests a copyist error. We can reasonably assume that the poet is not speaking about himself in lines 2 and 3 , when he mentions 'he who rules within the compass (or on the outskirts: pagěr) of Amla' and, further, that an original second line may have provided a link to the patron of this work. Zoetmulder does not indicate the manuscript he used and I have not been able to verify the reading. 
tions from the HKS Collection, HKS 1469 and HKS 5248. The two HKS transcriptions match Pigeaud's brief description (1980:191) that the Kakawin concerns 'the story of Sumantri, a member of the Bhärgawa family and his younger brother Sukasarana'. In the Kakawin, Sumantri, who in Javanese wayang is known as Arjuna Sahasrabāhu's younger brother, becomes Arjuna's patih. He is called Suwanda. Arjuna himself plays a minor role. The text, replete with numerous battle scenes, includes in its cast of characters the many vassal kings familiar from other epic tales, including the Sumanasāntaka, Rāmawijaya, Arjunawijaya and Ràmaparaśuwijaya, chief amongst whom are the rulers of Magadha and Widarbha. The intertextual links with Old Javanese literature more broadly are clear, but the precise source of this poem remains unresolved. I have not been able to trace the text Zoetmulder cites as the Sumantri.

As noted above, there are two transcriptions of this Kakawin in the HKS Collection: HKS 1469 where it is called Kakawin Sumantri and HKS 5248 where it is given the title Kakawin Mahispati. ${ }^{20}$ There are some differences between the two texts, but they derive from a common source. HKS 5248 comprises 43 cantos. HKS 1469 omits cantos 14-28, and ends at Canto 41 (erroneously numbered $50[\mathrm{~L}]$ in the transcription) and finishes with a three-stanza epilogue. There are other minor variations in readings and, here and there, an extra or omitted stanza. The epilogues are paraphrases of each other and closely interrelated. Both mention that the poem is written in homage to Sang Mapandhya Wara Buddha and both appear to contain a chronogram date in the last stanza but the interpretation is uncertain. HKS 1469 mentions the place of copying as the Aśramākara Nirarșa Nagārāmlapura. Nirarṣa is synonymous with Singarsa, that is, Sidemen, Karangasem, an important, if not the leading literary centre in the seventeenth to nineteenth centuries and this information thus links this transcription with the Karangsem provenance of the version of the Sumantri cited by Zoetmulder. ${ }^{21}$

The catalogues also include two additional Kakawins that may be connected to the UtK cycle, one dealing with Rāwana's early history, and the other with the Arjunawijaya story. Both are very short texts. The first of these, the Śakakäla, comprises just seven cantos. It dates from the late nineteenth century and relates the struggle of Rāwaṇa and Māruta. A Kakawin with this title is named as one of Prapañca's works in the Deśawarnana but there is no evidence to suggest

20. HKS 1302 (LOr 13.759) and HKS 3304 which also bear the title Mahispati are copies of the Arjunawijaya. HKS 3304 includes a Balinese gloss.

21. There are Gaguritans and Parikans called Sumantri in the HKS Collection (HKS 1222, HKS 2484) but these are not connected to the Rämāyana story, nor it would seem to the Kakawin Sumantri/Mahispati described here. 
the reference is to the Śakakala described here. Two other short Kakawins are included in the same lontar, the Padma Sari, and another dealing with smoking opium and gambling which has a colophon dated 1810 śaka 1888 AD (Pigeaud 1968:855).

The other, the Wiśálāgni, is unfinished. It is an Arjuna Sahasrabāhu tale, which Pigeaud (1967:196) describes as being like the Arjunawijaya.

\section{The Next Chapter...}

There can be no doubt that the broad Rāmàyana epic tradition remained a core literary focus in premodern Bali. Although there are a considerable number of Kidung and Gaguritan works, as well as various prose works and summaries that take up the Rammayana story, it is not possible here to deal with the entire complex of Balinese Rāma stories and the discussion has therefore been confined to works belonging to the Kakawin genre. It is also necessary to leave for another occasion the discussion of the myriad adaptations of the Rāmàya$n a$ in other genres, both traditional and modern, such as wayang, painting and the performing arts, not to mention modern literary and performance adaptations, although these too might legitimately be considered part of the story of the Rāmāyana in Bali. Vickers takes up one example in his contribution to this volume.

To return briefly to my starting point: the 2002 Kakawin Rāwana by I Wayan Pamit. This very recent Kakawin represents a radical change in Balinese approaches to Kakawin composition. No longer requiring the painstaking production of a palm-leaf lontar manuscript, it has been written on a computer and mass produced. It can be re-produced infinitely and on demand. The tanah and karas, the pengutik and leaf of the tal tree have been set aside. The text still uses Balinese aksaras, but now the letters are a uniform shape and size; there may still be the occasional scribal (typographical) error, but mistakes and quirky, idiosyncratic changes in readings, as minds skip ahead and letters change physical shape, unnoticed, are unlikely to creep into this text on account of human limitations, to be passed to the next generation. The text has become fixed and static. The text as artefact has presumably also lost its sacred character; the aksaras will no longer ebb and flow. The poem retains its introductory manggala there on page one in the form of a Preface, which still incorporates the formulaic apology for its inadequacies - that tradition has not yet died. The poet is no longer anonymous, no longer does he hide behind a parab; not only his name is there, so too is his photograph. He has been interviewed for the newspapers. He is a modern kawi. 
Against all odds, 'traditional' Balinese literature continues to defy those dire predictions in the 1980 s and 1990 os that manuscript-based literary forms would die. But there is certainly change and transformation. Twenty-first century Kakawin composition may remain a niche area of creative endeavour, but the study of Bali's literary heritage, and the composition of new works, seems to be going from strength to strength, via the medium of electronic broadcasting. Kakawin poetry has always been a dynamic genre, has always responded to cultural and technological change. It remains a part of Balinese creative life. A millennium on, it is not too difficult to imagine that there may well be many more chapters to come in the Rámāyana story in Bali. 

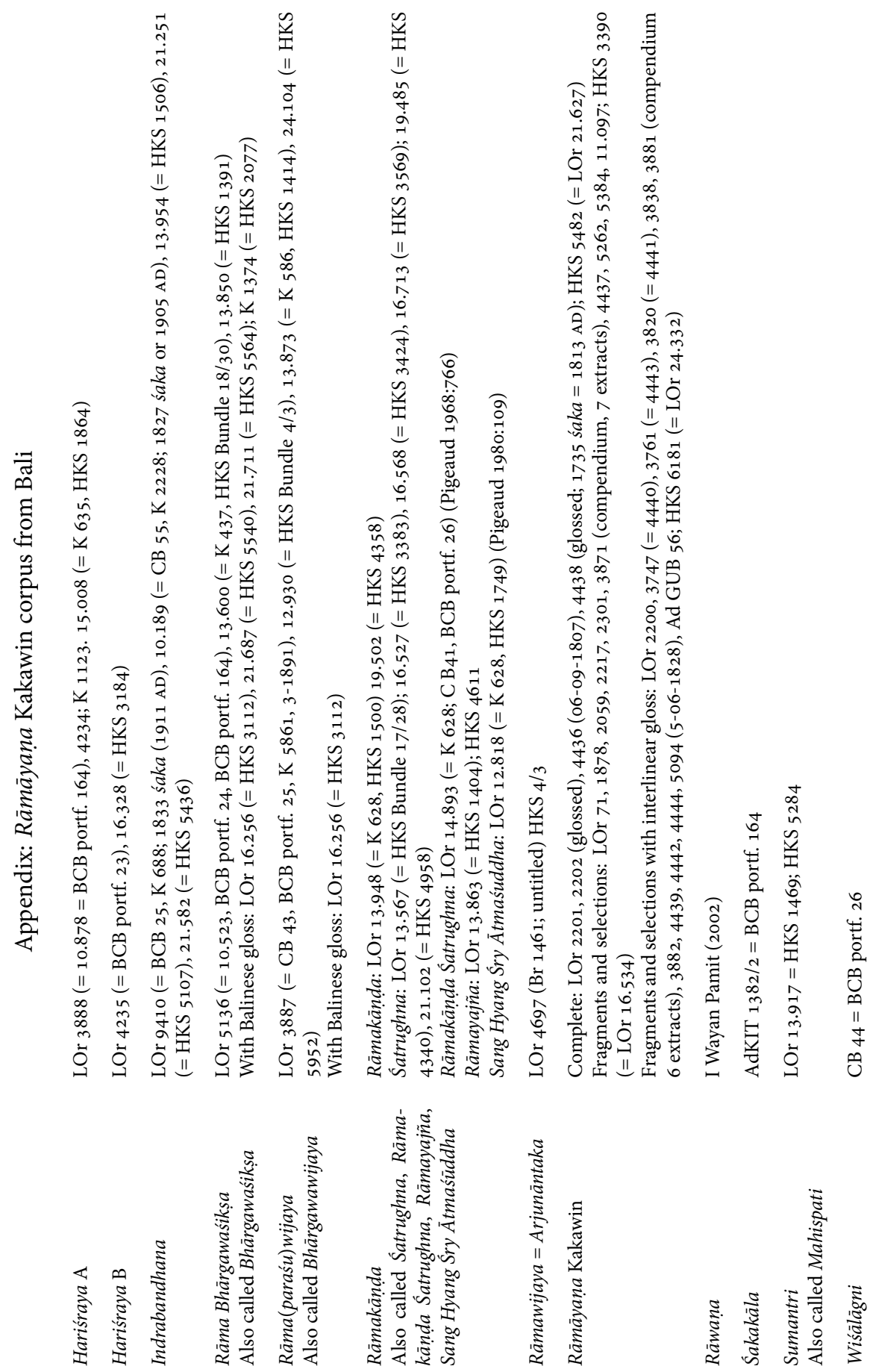